\title{
ÖSSZETETT MÜTRÁGYA, GRANULÁLT SZERVESTRÁGYA ÉS PATENTKÁLI HATÁSA GUMÓS ZELLER TERMÉSÉRE HOMOKTALAJON, TENYÉSZEDÉNY KÍSÉRLETBEN
}

\section{EFFECT OF COMPLEX FERTILIZER, GRANULAR ORGANIC FERTILIZER AND POTASSIUM FERTILIZER ON THE CROP OF CELLERY ON SAND SOIL, IN GROWING POTS}

\author{
Cserni Imre, Hüvely Attila, Petö Judit
}

*Agrártudományi Tanszék, Kertészeti és Vidékfejlesztési Kar, Neumann János Egyetem, Magyarország https://doi.org/10.47833/2021.1.AGR.003

\section{Kulcsszavak: \\ Homoktalaj \\ Tápanyag-szolgáltatás \\ Szerves trágya \\ Kálium trágyázás \\ Gumós zeller}

\section{Keywords:}

Sandy soil

Nutrient supply

Organic fertilizer

Potassium fertilizer

Celery

\section{Cikktörténet:}

Beérkezett 2021. március 18. Átdolgozva 2021. március 25. Elfogadva 2021. április 3.

\begin{abstract}
Összefoglalás
Jelen tanulmányunk alátámasztja, hogy a kolloidokban szegény homoktalajokon a szabadföldi zöldségtermesztés esetén rendkívül nagy jelentősége van a szervestrágyázásnak. Kísérletünket a NJE Kertészeti Karának belső kertjében, liziméteres tenyészedényekben, kecskeméti lepelhomok talajon, gumós zeller jelzőnövénnyel végeztük 2019-ben. A kísérlet célja volt, hogy megvizsgáljuk igen gyenge humusz: (H\%: 0,42 m/m\%) és nitrogén, valamint igen jó foszfor és közepes kálium tápanyag ellátottság mellett, miként reagál a gumós zeller az összetett mütrágyára, a káliumszulfátra és a granulált szervestrágyázásra. Az eredmények szerint a csak nitrogént kapott kezelés adta a legkisebb terméstömeget. Az összetett mütrágya plusz Patent káli (75 kg/ha hatóanyag) adaggal adta a legkedvezöbb ( $\mathrm{g} / \mathrm{db})$ termést. A granulált szervestrágya plusz összetett mütrágyás kezelés pedig a legnagyobb zellergumó tömegtermést eredményezte.
\end{abstract}

\begin{abstract}
Our present study confirms that organic fertilization is extremely important in open field vegetable growing on colloid-poor sandy soils. Our experiment was carried out in 2019 in the inner garden of the Faculty of Horticulture, in lysimeter growing pots, on Kecskemét cover soil, with a tuberous celery marker plant. The aim of the experiment was to investigate very weak humus: $(\mathrm{H} \%$ : $0.42 \mathrm{~m} / \mathrm{m} \%$ ) and nitrogen, very good phosphorus and medium potassium nutrient supply, how tuberous celery reacts to complex fertilizers, potassium sulphate and granular organic fertilizer. The results showed that treatment with nitrogen alone yielded the lowest yield. The compound fertilizer plus patent
\end{abstract}

\footnotetext{
* Pető Judit. Tel.: +36 76517661

E-mail cím: peto.judit@kvk.uni-neumann.hu
} 
potassium (75 kg/ha) gave the best yield (g/pcs.). The granular organic fertilizer plus complex fertilizer treatment resulted the highest celery tuber mass yield.

\section{Bevezetés}

A kolloidokban szegény homoktalaj tápanyag-szolgáltatása, vízgazdálkodása, pufferoló képessége rendkívül gyenge. Meszes homoktalajokon a talaj szerkezetre kifejtett hatása a szerves trágyáknak különösen jótékony hatású [1].

A kísérlet célja volt, hogy megvizsgáljuk, hogy igen gyenge humusz $(0,42 \%)$, és $\left(\mathrm{NO}_{3}{ }^{-}+\mathrm{NO}_{2}{ }^{-}\right)^{-}$ nitrogén $(2,12 \mathrm{mg} / \mathrm{kg})$ tartalmú talajon, és igen jó foszfor $\left(A L-\mathrm{P}_{2} \mathrm{O}_{5} 297 \mathrm{mg} / \mathrm{kg}\right)$, valamint közepes kálium ( $\mathrm{AL}-\mathrm{K}_{2} \mathrm{O}$ 46,2 $\mathrm{mg} / \mathrm{kg}$ ) és 70-80 mg/kg vízoldható $\mathrm{Mg}$ tápanyag ellátottság mellett a meszes homoktalajainkon a különböző trágyák miként befolyásolják a zeller termését és a terméselemek egymáshoz viszonyított arányát. Az alkalmazott trágyafajták az Orgevit granulált szervestrágya. az összetett mütrágya: NovaTec classic, valamint a $\mathrm{K}_{2} \mathrm{SO}_{4}$ tartalmú Patentkáli különböző adagjai voltak. A Patentkáli mütrágyában a kálium és a magnézium is szulfát formában van jelen. A vízoldható kálium 30\% $\mathrm{K}_{2} \mathrm{O}$-t és ugyancsak $10 \%$ vízoldható $\mathrm{MgO}$-ot, valamint $17 \%$ vízoldható elemi S-t tartalmaz. A Patentkáli mütrágyát azért alkalmaztuk, mert kíváncsiak voltunk, hogy a Patentkáliban lévő magnézium befolyásolja-e a termés minőségét vagy mennyiségét.

A magnézium a meszes homoktalajainkban kisebb, míg kötöttebb talajokban nagyobb mennyiségben fordul elö. Hazánkban a kilúgozott barna erdőtalajokban és savanyú homoktalajokban fordul elö lekisebb mennyiségben [2, 3]. A talajoldat Mg tartalmát a kicserélhetö, az oldható ill. mobilizálható készletek együtt szabják meg. A Duna-Tisza közi homoktalajainkon ez ideig nem tudunk magnézium hiányról.

Korábbi, gumós zellerrel végzett kísérleti eredményeik szerint már igazolódott a szervestrágya plusz összetett mütrágya gumótermésre kifejtett pozitív hatása $[4,5,6]$. Kevésbé ismert azonban a kiskertekben egyre gyakrabban alkalmazott összetett mütrágyaféleségek, mint a (NovaTec) és a granulált baromfitrágya (Orgevit), valamint a Patentkáli gumós zeller termésére és terméselemeire gyakorolt hatása. A 2019-ben beállított kísérletünkben arra kerestük a választ, hogy a provokatív adagú, $\mathrm{K}_{2} \mathrm{SO}_{4}$ formájú, kálium dózisok miként befolyásolják a terméseredményeket.

\section{Anyag és módszer}

A kísérletet a Neumann János Egyetem, Kertészeti és Vidékfejlesztési Kar Agrártudományi Tanszék belső tenyészkertjében végeztük. 2019-ben, átfolyó liziméteres, $0,3 \mathrm{~m}^{2}$ felületü, 1/3 köbméteres, földbe süllyesztett tenyészedényekben történtek a vizsgálataink. A kísérlet talajtípusa a váztalajok fő típusába tartozó, futóhomok típusú lepelhomok talaj volt. A kísérlet talaja a ZKI Borbás pusztai területéröl származik, melyet eredetileg 1995-ben állítottunk be. Az eltelt negyedszázad alatt az edényekben a talaj jól beált. A beállításnál vigyáztunk arra, hogy a $0-30 \mathrm{~cm}-$ es termőréteg kerüljön felülre, és a 31-60 cm-es réteg alulra. Az eltelt időszakban a tenyészedényekben különböző trágyakezeléseket alkalmaztunk [4, 5, 6, 7, 8, 9].

A talajmintákat a korábbi 4 ismétléses, 6 kezeléses tenyészedény kísérletek kezelésenkénti homogenizálásával állítottuk elő. $\mathrm{Az}$ 1. Táblázat a 6 kezeléses tenyészedény kísérlet mütrágyaszórás előtti (2019), főbb talajvizsgálati eredményeit tartalmazza (a kar akkreditált Talajés Növényvizsgáló Laboratóriumának jegyzőkönyve alapján).

A kísérletben, 2019-ben is, 6 kezelést alkalmaztunk, 4 ismétléssel. 
1. Táblázat. Talajvizsgálati eredmények a 2019 évi kezelések elött

\begin{tabular}{|l|c|c|c|c|c|c|c|c|c|}
\hline & $\begin{array}{c}\mathrm{pH} \\
\left(\mathrm{H}_{2} \mathrm{O}\right)\end{array}$ & $\begin{array}{c}\mathrm{pH} \\
(\mathrm{KCl})\end{array}$ & $\mathrm{K}_{\mathrm{A}}$ & $\begin{array}{c}\text { Összes } \\
\text { só } \\
\mathrm{m} / \mathrm{m} \%\end{array}$ & $\begin{array}{c}\mathrm{CaCO}_{3} \\
\mathrm{~m} / \mathrm{m} \%\end{array}$ & $\begin{array}{c}\mathrm{H} \% \\
\mathrm{~m} / \mathrm{m} \%\end{array}$ & $\begin{array}{c}\left.\mathrm{NO}_{2} \mathrm{NO}_{3}\right) \cdot \mathrm{N} \\
\mathrm{m} / \mathrm{m} \%\end{array}$ & $\begin{array}{c}\mathrm{AL}-\mathrm{P}_{2} \mathrm{O}_{5} \\
\mathrm{~m} / \mathrm{m} \%\end{array}$ & $\begin{array}{c}\mathrm{AL}-\mathrm{K}_{2} \mathrm{O} \\
\mathrm{m} / \mathrm{m} \%\end{array}$ \\
\hline Kontroll talaj & 7,55 & 7,36 & 26 & 0,02 & 1,35 & 0,42 & 2,12 & 297 & 46,2 \\
\hline $\begin{array}{l}\text { Korábbi } \\
\text { kezelések } \\
\text { kevert talaja }\end{array}$ & 7,53 & 7,39 & 27 & 0,02 & 1,51 & 0,72 & 3,33 & 428 & 95,7 \\
\hline
\end{tabular}

A NovaTec classic (12:8:16) összetett mütrágyát $600 \mathrm{~kg} / \mathrm{ha}$ dózisban és az Orgevit granulált, szárított szarvasmarha szerves trágyát $1600 \mathrm{~kg} / \mathrm{ha}$ dózisban, a talaj forgatása elött (2019.05.17.), alaptrágyaként szórtuk ki, majd $15-20 \mathrm{~cm}$ mélyre, a talajba forgattuk. A N-mütrágya $\left(34 \% \mathrm{NH}_{4} \mathrm{NO}_{3}\right)$ és a Patentkáli $\left(30 \% \mathrm{~K}_{2} \mathrm{SO}_{4}\right)$ felét a palánta kiültetésekor, fejtrágyaként adtuk, a felszínre szórva jól beöntöztük, míg a másik felét a tenyészidő alatt (augusztus derekán) a felszínre szórva, beöntözve, fejtrágyaként alkalmaztuk (2. Táblázat).

2. Táblázat. A trágya kezelések NPK hatóanyag tartalma

\begin{tabular}{|c|c|c|c|c|c|c|c|c|c|}
\hline \multicolumn{2}{|c|}{$\begin{array}{l}\text { Kezelések és } \\
\text { rövidítésük }\end{array}$} & \multicolumn{3}{|c|}{ Orgevit $1600 \mathrm{~kg} / \mathrm{ha}$} & \multicolumn{3}{|c|}{ NovaTec $600 \mathrm{~kg} / \mathrm{ha}$} & \multirow{2}{*}{$\begin{array}{c}\text { Patentkáli } \\
(30 \%)\end{array}$} & \multirow{2}{*}{$\begin{array}{c}\mathrm{NH}_{4} \mathrm{NO}_{3} \\
(34 \%)\end{array}$} \\
\hline & & $\begin{array}{c}\mathrm{N} \\
(\mathrm{kg} / \mathrm{ha}\end{array}$ & $\begin{array}{l}\mathrm{P}_{2} \mathrm{O}_{5} \\
(\mathrm{~kg} / \mathrm{ha})\end{array}$ & $\begin{array}{c}\mathrm{K}_{2} \mathrm{O} \\
(\mathrm{kg} / \mathrm{ha})\end{array}$ & $\underset{(\mathrm{kg} / \mathrm{ha})}{\mathrm{N}}$ & $\begin{array}{l}\mathrm{P}_{2} \mathrm{O}_{5} \\
(\mathrm{~kg} / \mathrm{ha})\end{array}$ & $\begin{array}{c}\mathrm{K}_{2} \mathrm{O} \\
(\mathrm{kg} / \mathrm{ha})\end{array}$ & & \\
\hline 1 & N100 & & & & & & & & 100 \\
\hline 2 & NT & 64 & 40 & 36,8 & 72 & 48 & 96 & & \\
\hline 3 & $\begin{array}{lll}\mathrm{Pk} & 0 & \mathrm{NT} \\
\end{array}$ & & & & 72 & 48 & 96 & & \\
\hline 4 & Pk 135 NT N100 & & & & 72 & 48 & 96 & 135 & 100 \\
\hline 5 & Pk $90 \quad$ NT N100 & & & & 72 & 48 & 96 & 90 & 100 \\
\hline 6 & 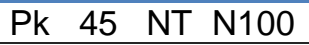 & & & & 72 & 48 & 96 & 45 & 100 \\
\hline
\end{tabular}

Jelmagyarázat: \#=szervestrágya, NT=NovaTec, Pk =Patentkáli

A kísérlet jelzőnövénye a gumós zeller (Apium graveolens convar. rapaceum) volt. A palántákat a mütrágyakezelés után, májusban ültettük ki, tenyészedényenként 5 növényt.

A tenyészedényeket mechanikai módszerekkel gyommentes állapotban tartottuk. $A z$ öntözést esőszerü öntözéssel végeztük, a növény igényei szerint. A betakarítást a tenyészidőszak végén, piacos fejlettségi állapotban végeztük, 2019 októberében. A termés tömegeket (levél, gumó és gyökér) kezelésenként és ismétlésenként grammos mérlegen lemértük. A mintákat megtisztítás után a kar laboratóriumába szállítottuk.

\section{Eredmények és értékelés}

A gumótermés eredmények azt mutatják, hogy a kontroll (1. ábra, 1. kezelés) adta a legkisebb gumó termést, (52,5 g/tenyészedény, a továbbiakban: g/te), - ami várható is volt, - mivel a talaj igen gyenge $\left(\mathrm{H} \%=0,42, \quad\left(\mathrm{NO}_{2}+\mathrm{NO}_{3}\right) \mathrm{N}=2,12 \mathrm{mg} / \mathrm{kg}\right)$ nitrogén ellátottságú. A nitrogén $(100 \mathrm{~kg} / \mathrm{ha}$ hatóanyag) hatása nem jelentkezett, jóllehet a minimumban lévő tényezőnek számított. Ennek oka feltételezésünk szerint, - melyet korábbi kísérleteink is alátámasztanak, - a $\mathrm{N}$ jelentős kimosódása homoktalajainkon ( $\left.\mathrm{K}_{\mathrm{A}}: 26\right)$, ami az alkalmazott adagok nagyságától és az öntözővíz mennyiségétöl függően $30-40 \%$-ot is elérheti [7, 8, 9, 10, 11, 12].

Ezzel szemben a legnagyobb gumótermést az összetett mütrágya NovaTec classic és Ogevit szervestrágyás kezelés eredményezte (346,6 g/te, 2. kezelés, 1. ábra). A szervestrágyás kezelés eredménye egyértelműen alátámasztja, hogy a homoktalajaink ásványi és szerves kolloid tartalmának hiánya miatt a szervestrágya csodákra képes. A talaj kolloid tartalmának hiányát jelzik a talajvizsgálati eredmények is (1. Táblázat). Az Orgevit szerves trágya plusz a NovaTec komplex 
műtrágya folyamatos tápanyag-ellátást, trágya- és biológia aktivitást, talaj szerkezet- és vízgazdálkodását javító hatása mellett jelentősen hozzájárulhatott, befolyásolhatta a homoktalaj tápanyag-szolgáltató képességét is.

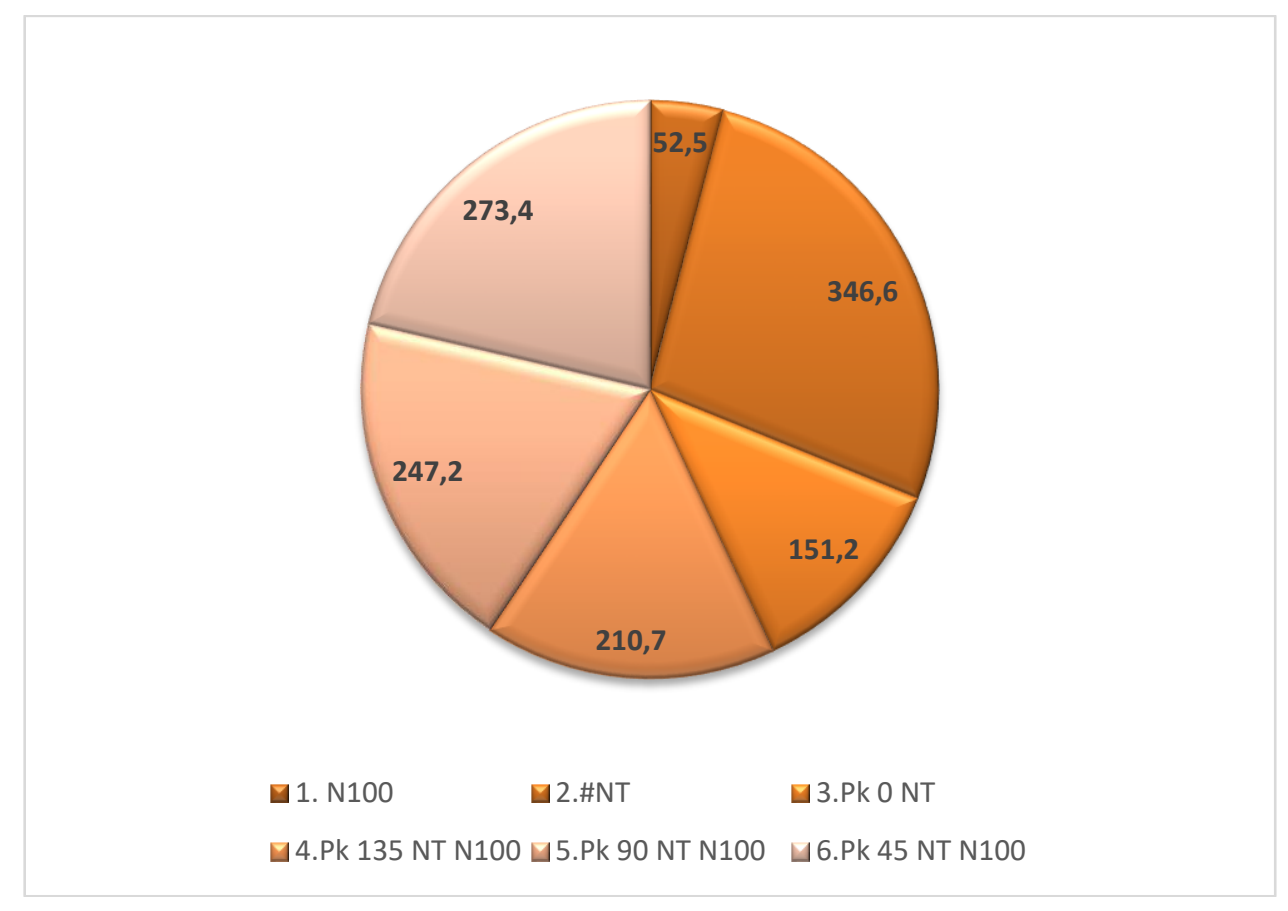

1. ábra. A gumós zeller gumó termésének ( $g / t e)$ megoszlása kezelésenként

A talajvizsgálati eredmények azt látszanak indokolni, hogy elegendő lenne csak nitrogén tápanyagot pótolni ahhoz, hogy elfogadható termést kapjunk. Igen ám, de a nitrogén hatékonysága homoktalajon rossz, plusz még meg kell említenünk, hogy ezek a tenyészedények már évek óta a nem kaptak nitrogén utánpótlást. A Pko-s (csak NovaTec kontroll, 3.kezelés) 151,2 g/te, a legnagyobb adagú patentkális (Pk135 + NT + N100, 4.kezelés 210,7 g/te produkált. A kisebb K hatóanyag tartalmú kezelés (5. kezelés) ennél nagyobb, 247,2 g/te gumótermést képzett. A mikroelemekkel kiegészített, NovaTec classic mütrágya $(600 \mathrm{~kg} / \mathrm{ha})$ a legkisebb $(45 \mathrm{~kg} / \mathrm{ha})$ patentkálival, valamint $100 \mathrm{~kg} / \mathrm{ha} \mathrm{N}$ hatóanyaggal kiegészítve (6. kezelés) a káliumos kezelések közül a legnagyobb gumótermést eredményezte (273,4 g/te). A provokatívan nagy adag Patentkáli (225 kg/ha) már depresszív hatásúnak bizonyult.

A biomassza tenyészedényenkénti termésmennyiségét vizsgálva megállapítható, hogy a legnagyobb biomassza tömeget - úgy, mint a gumó termés esetében is - a szerves trágyás kezelés eredményezte (468 g/te, 2. ábra).

A Pko-s NT kontrollhoz mérten (3. kezelés), a teljes biomassza tömeg szintén növekedett, meglepetésünkre - a patentkáli adagok csökkenésével. Ez arra hívja fel a figyelmet, hogy a patentkáli túlzottan nagy adagja már negatívan befolyásolhatja a gumós zeller biomassza termését.

A darabonkénti tömegtermést tekintve is némileg hasonló tendenciákat figyeltünk meg, azonban a 4., 5. és 6. kezelések között a különbség nem volt jelentős (2. ábra). 


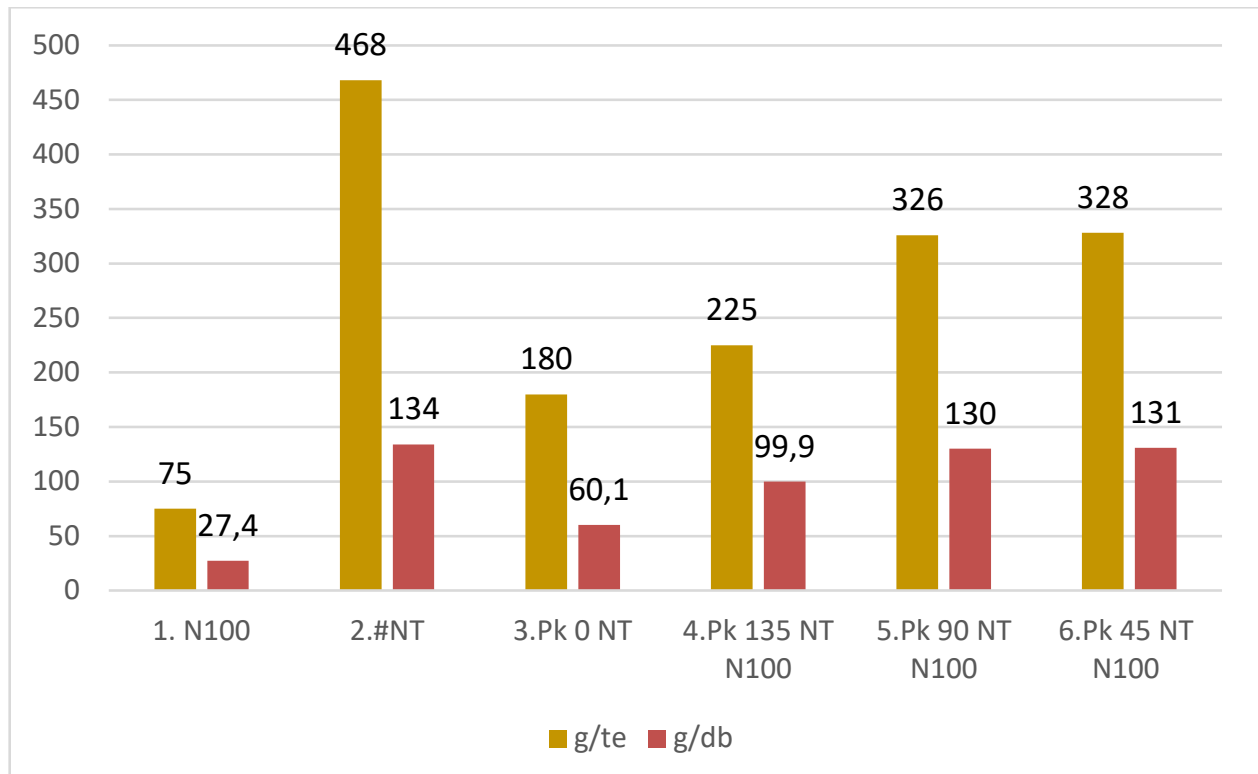

2. ábra. A gumós zeller teljes biomassza tömege ( $g / t e)$ és a tényleges darabonkénti átlagos biomassza tömege ( $\mathrm{g} / \mathrm{db})$, kezelésenként

A terméselemek, értékelése figyelemre méltó eredményeket jelzett, melyet előző évi kísérleteink is igazoltak [4,5].

A legnagyobb patentkálit kapott kezelés volt a legnagyobb pozitív hatással a gumóképződésre: $79,3 \%$ (4. kezelés, 3. ábra). A levél képződésére viszont a csak nitrogént kapott kezelés volt előnyös: 25,2\% (1.kezelés 3.ábra). Ez igazolja azt a tényt, hogy a nitrogén tápanyag a zöld tömegképződésért felelős, míg a káliumnak a gumóképződésre kifejtett hatása volt a legnagyobb, azaz a minőségért felelős. Annak ellenére, - mint már említettük, - az összes gumótömegre kifejtett hatása (1. ábra) a legnagyobb adagú patentkálinak csak 210,7 g/te gumótermést eredményezett. A kálium adagok 2019-ben is növelték a gumók arányát - kezeléseken belül - a levél, gyökér és gumó vonatkozásában.

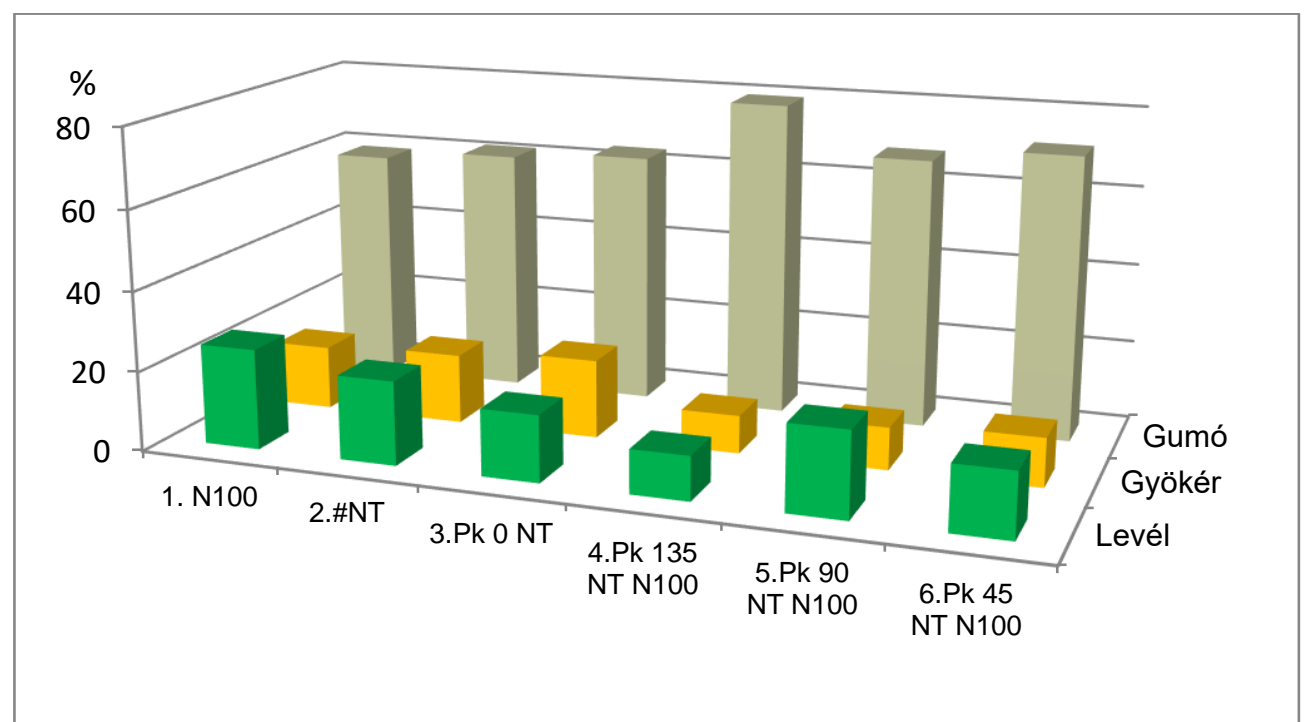

3. ábra. A gumós zeller növényi részeinek százalékos alakulása kezelésenként 


\section{Következtetések}

Kísérleti adataink szerint - a homok mechanikai jellegü talajok igen kicsi kolloid tartalmának köszönhetöen - a gumós zeller termesztése során a szervestrágya használata feltétlenül indokolt.

A legnagyobb biomassza tömeget a szervestrágyás (Orgevit) kezelés eredményezte.

A patentkáli túlzottan nagy adagjai negatívan hatottak a termés mennyiségére és a tényleges darabonkénti terméstömegre.

A terméselemek vizsgálata azonban a patentkáli gumóképződésre kifejtett kedvező hatását jelezte.

\section{Köszönetnyilvánítás}

Köszönetünket fejezzük ki mindazon kollégáknak, akik a technikai kivitelezésben és a mérésekben segítségünkre voltak.

\section{Irodalomjegyzék}

[1] Cserni I., Pető J., Hüvely A. (2017): Homoktalajok tápanyag-tartalma a tápanyag-ellátás függvényében. Talajvédelem. 25. Különszám, 2017. pp.351-362.

[2] Győri D. (1984): A talaj termékenysége. Franklin Nyomda, Budapest, 254 p.

[3] Loch J. (1999): Magnéziumtrágyázás. in Füleky Gy.Tápanyag-gazdálkodás.714.p.

[4] Cserni, I., Pető J., Hüvely A. (2017): A zeller növekedésének és egyes értékmérő paramétereinek vizsgálata. GRADUS 2. 2. pp. $236-241$

[5] Cserni I., Hüvely, A., Pető, J. (2019): Gumós zeller (Apium Graveolens Convar. Rapaceum) kálium trágyázási kísérlet GRADUS 6: 2. pp.116-121.

[6] Cserni, I., A. Hüvely, J. Petö (2020): The impact of potassium fertilization on development and magnesium content of celery. GRADUS 7. 3 pp. 57-61.

[7] Cserni I., Végh R. K., Füleky Gy. (2000): Tápelemek modellezése és mérése a talajban zöldségnövények alatt. Kutatási zárójelentés a T 023348 OTKA témáról.1997-1999. (Kézírat) 50. p.

[8] Végh, K. R., I. Cserni (2001): Measured and simulated nitrate leaching in vegetable culture. Plant nutrition. Food security and sustainability of agro-ecosystems. pp. 936-937.DOI $0.1007 / 0-306-47624-X$

[9] Cserni, I. N. Kovács, A. Zana A., J. Borsné Pető (2004): The migration of elements (N,P,K) in sandy soil III. ALPSADRIA SCIENTIFIC WORKSHOP. 1-6 March 2004. Dubrovnik, Croatia. pp.30-34. DOI: 10.12666/Novenyterm.63.2014.Suppl

[10] Buzás., I., E. Hoyk, I. Cserni, J. Bors-Pető (2006): Calibration of nitrogen content of soil with sweet corn. AGROKÉMIA ÉS TALAJTAN 55. 1. pp. 223-230.

[11] Buzás I., Hoyk E., Cserni I., Borsné Pető, J. (2006): Talaj nitrát-vizsgálati értékek kalibrálása a csemegekukorica nitrogén mütrágya adagjának meghatározása céljából. Előadások és poszterek összefoglalója. Talajtani Vándorgyülés. Sopron 2006. augusztus 23-25. p. 3.

[12] Buzás I., E. Hoyk, I. Cserni, J. Borsné Pető (2006): Evaluation of the optimum nitrogen fertilizer depending on the soil in sweet corn plantation. CEREAL RESEARCH COMMUNICATIONS 34: pp. 421-424. https://doi.org/10.1556/CRC.34.2006.1.105 